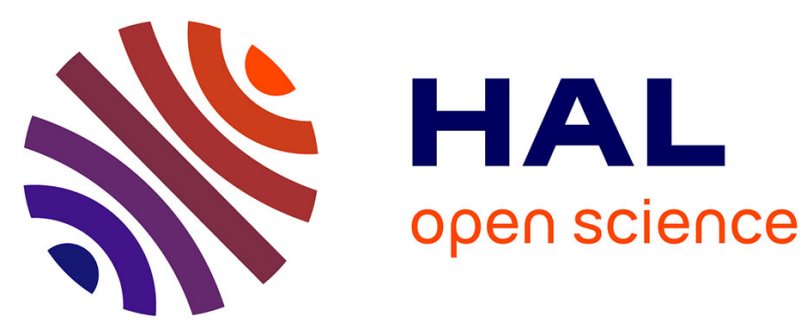

\title{
Short-term forecasting of cyanobacteria blooms in Yuqiao reservoir, China
}

Brigitte Vinçon-Leite, Ali Fadel, Bruno J. Lemaire, Céline Bonhomme, Yinghao Li, Gwendal Le Divechen, Jun Zhang, Yang Luo

\section{To cite this version:}

Brigitte Vinçon-Leite, Ali Fadel, Bruno J. Lemaire, Céline Bonhomme, Yinghao Li, et al.. Shortterm forecasting of cyanobacteria blooms in Yuqiao reservoir, China. La Houille Blanche - Revue internationale de l'eau, 2017, 2, pp.35 - 44. 10.1051/lhb/2017015 . hal-01578787

\section{HAL Id: hal-01578787 \\ https://hal-enpc.archives-ouvertes.fr/hal-01578787}

Submitted on 26 Jun 2018

HAL is a multi-disciplinary open access archive for the deposit and dissemination of scientific research documents, whether they are published or not. The documents may come from teaching and research institutions in France or abroad, or from public or private research centers.
L'archive ouverte pluridisciplinaire HAL, est destinée au dépôt et à la diffusion de documents scientifiques de niveau recherche, publiés ou non, émanant des établissements d'enseignement et de recherche français ou étrangers, des laboratoires publics ou privés. 


\title{
Short-term forecasting of cyanobacteria blooms in Yuqiao reservoir, China
}

\author{
Brigitte VINÇON-LEITE ${ }^{1}$, Ali FADEL ${ }^{2}$, Bruno J. LEMAIRE ${ }^{3}$, Céline BONHOMME ${ }^{4}$, Yinghao LI ${ }^{5}$, \\ Gwendal LE DIVECHEN ${ }^{6}$, Jun ZHANG $^{7}$, Yang LUO ${ }^{8}$
}

\author{
1. Laboratoire Eau Environnement Systèmes Urbains (LEESU), Université Paris-Est, Ecole des Ponts ParisTech, Champs-sur-Marne, France - \\ b.vincon-leite@enpc.fr \\ 2. National Center for Remote Sensing, National Council for Scientific Research (CNRS), Riad El Solh, Beirut, Lebanon-afadel@cnrs.edu.lb \\ 3. Laboratoire Eau Environnement Systèmes Urbains (LEESU), AgroParisTech, Paris, France - bruno.lemaire@enpc.fr \\ 4. Laboratoire Eau Environnement Systèmes Urbains (LEESU), Université Paris-Est, Ecole des Ponts ParisTech, Champs-sur-Marne, France- \\ celine.bonhomme@enpc.fr \\ 5. Laboratoire Eau Environnement Systèmes Urbains (LEESU), Université Paris-Est, Ecole des Ponts ParisTech, Champs-sur-Marne, France- \\ yinghao.li@enpc.fr \\ 6. International Office for Water, Sophia Antipolis, France-g.le-divechen@oieau.fr \\ 7. Hai River Water Environmental Monitoring Center, Hai River Water Conservancy Commission, Ministry of Water Resources, Tianjin, China - \\ zhangjun506@163.com \\ ${ }^{8}$ Hai River Water Environmental Monitoring Center, Hai River Water Conservancy Commission, Ministry of Water Resources, Tianjin, China - \\ luoyang@hwcc.gov.cn
}

ABSTRACT. - Agriculture fertilizers and untreated sewage in the catchment of freshwater bodies increase their nutrient concentrations. The resulting eutrophication promotes phytoplankton blooms, in many cases of toxic cyanobacteria. Ecological models can simulate the main processes driving algal blooms. They help to understand how phytoplankton responds to different forcing. Another major use of models is as predictive tool supporting the management of water resources. Yuqiao Reservoir is the main drinking water source for Tianjin, the fifth most populated city in China. During the last decade, drinking water production has been impaired by recurrent cyanobacteria blooms. The water quality management of the reservoir, conducted by the Hai River Water Conservancy Commission, requires an early warning system in order to anticipate the cyanobacteria blooms and to adapt the treatment process. Therefore, within the framework of a French-Chinese project on Integrated Water Resources Management (IWRM) of the catchment of the Hai river, a modelling approach of cyanobacteria growth, which could be later embedded in an early warning system, was proposed. In this study, we calibrated a one-dimensional vertical, physical-ecological model aimed at forecasting cyanobacteria blooms in the Yuqiao Reservoir. We first introduce the study site and its ecological status. Then we describe the model and the input data set. The calibration and validation results are presented for water temperature and chlorophyll-a concentration at the measurement dates. The short-term forecast modelling is performed for temperature and cyanobacteria over a 5-day ahead period. Two weather scenarios are considered: one favourable for cyanobacteria and one disfavourable.

Key-words: deterministic model, temperature, phytoplankton, vertical profiles, meteorological forecast.

\section{Modélisation prédictive des proliférations de cyanobactéries dans le réservoir Yuqiao, Chine}

RÉSUMÉ. - L'agriculture et le traitement insuffisant des eaux usées dans les bassins versants de nombreux lacs et réservoirs sont à l'origine de concentrations en nutriments élevées dans ces milieux. L'eutrophisation qui en résulte menace la qualité des ressources en eau, car elle favorise les proliférations phytoplanctoniques, notamment celles des cyanobactéries, espèces potentiellement toxiques. La modélisation écologique permet de représenter les principaux processus qui contrôlent ces proliférations algales. Prenant en compte les interactions entre les processus, elle permet de comprendre comment le phytoplancton réagit à différents forçages. La modélisation prédictive peut être utilisée dans l'aide à la décision pour la gestion des ressources en eau. Le réservoir de Yuqiao est la principale source d'eau potable pour la ville de Tianjin, cinquième ville la plus peuplée de Chine. Au cours de la dernière décennie, la production d'eau potable a été perturbée par des proliférations récurrentes de cyanobactéries. La gestion de la qualité de l'eau du réservoir est sous la responsabilité de la Commission de protection des eaux de la rivière Hai (HWCC). Afin d'anticiper l'arrivée de cyanobactéries toxiques à l'usine d'eau potable et d'adapter le processus de traitement, un système d'alerte lui serait très utile. Aussi, dans le cadre d'un projet franco-chinois sur la gestion intégrée des ressources en eau dans le bassin versant de la rivière Hai, une approche de modélisation des proliférations de cyanobactéries destinée à être intégrée ultérieurement à un système d'alerte, a été proposée. Dans cette étude, nous avons calibré un modèle vertical unidimensionnel thermique-écologique, visant à prévoir l'évolution de la biomasse des cyanobactéries dans le réservoir. Nous présentons le site d'étude et son état écologique. Nous décrivons ensuite le modèle thermique-écologique et le jeu de données utilisé. Les résultats des étapes de calibration et de vérification du modèle sont présentés pour la température de l'eau et la concentration en chlorophylle-a et comparés aux mesures. La modélisation prédictive à court terme de la température de l'eau et des cyanobactéries est illustrée sur un exemple d'une période de 5 jours en été. Deux scenarios de prévision météorologique, l'un favorable au développement des cyanobactéries et l'autre défavorable sont considérés.

Mots-clés : modélisation déterministe, température, phytoplancton, profils verticaux, prévisions météorologiques. 


\section{INTRODUCTION}

Eutrophication is a main concern in many water bodies worldwide. It is caused principally by excessive nutrient loading, mainly phosphorus but also nitrogen, from sewage and agriculture in the catchment. It results in phytoplankton blooms, whose final consequence is a limitation of the water body ecosystem services. The main effects include the reduction of water transparency, the depletion of oxygen concentration in the deep layers of the water column, the reduction of biodiversity. Among phytoplankton species, cyanobacteria including potentially toxic species can become dominant. Cyanobacteria represent a great concern worldwide; they disturb the ecosystem functioning and present health risks for human beings, livestock and wildlife. Real-time monitoring and forecasting the risk of cyanobacteria blooms are required for an effective management of water resources (Ye et al., 2014) and to take appropriate measures to protect population, e.g., to change drinking water processing or to shift to another resource, to prohibit temporarily fishing, irrigation or other water uses.

Few operational early warning systems of phytoplankton blooms have been developed during the last decades, either in the sea or in lakes, compared to the intense activity of the modelling research community. Anderson et al. (2012) review models for maritime blooms. Empirical models describe for instance a chain of observable meteorological events leading to a certain configuration of currents and to a bloom. Numerical models are most often three-dimensional hydrodynamic models with passive-tracking techniques that predict the extension of a bloom after its detection by remote sensing. Early warning systems based on coupled hydrodynamic and deterministic biological models are rare or under development. In lakes, one-dimensional hydrodynamic models describe properly the main features of the physical behaviour and can be used when the forecast is devoted to a limited area of interest. Three-dimensional models are now preferred for large lakes but still seldom used in early warning systems (Li et al., 2014; Zhang et al., 2013). For calibrating the model parameters and verifying its performances, three-dimensional models frequently use a huge dataset based on intensive monitoring at multiple points and remote sensing images (e.g. Jin et al., 2000; Curtarelli et al., 2014). Recent efforts however concentrate on statistical models and artificial neural networks, probably to avoid developing full coupled hydrodynamic and ecological models (Recknagel, 2013). But unless they are coupled with high-frequency monitoring, the forecasting performance of this type of models is low when the forcing conditions are changing rapidly.

In this context, our objective was to find a median way between the complex coupled hydrodynamic and ecological models and the rough, data-driven statistical models. We intended to develop a reliable but simple modelling tool for short-term forecasting of cyanobacterial blooms in the Yuqiao reservoir that provides drinking water to the city of Tianjin, in North-East China. Yuqiao reservoir has been undergoing serious eutrophication due to increased phosphorus inputs. During the last decade, the reservoir water quality has been seriously impaired by recurrent cyanobacterial blooms. In recent years, Microcystis novacekii was the dominant cyanobacteria species in Yuqiao reservoir (Huo et al., 2015). The forecasting model should be able to work also when no meteorological forecast is available near the reservoir but in a remote location $(50-100 \mathrm{~km})$ and without an autonomous on-line monitoring system.
In this paper, we present the historical data set which was used for defining the cyanobacteria growth model, the main features of the deterministic model we used, the calibration of the model parameters with data of summer 2014, and the outputs of the forecasting model.

This work was performed within the framework of a Cooperation project between the Ministry of Water Conservancy of China and the Ministry of Ecology, Sustainable Development and Energy (MEDDE) of France. The main objective of the overall project is to develop an operational plan for the integrated management of the Zhou River catchment, a sub-catchment of the Hai river where Yuqiao reservoir is located.

\section{MATERIAL AND METHODS}

\section{II.1. Study site}

The Yuqiao reservoir is located in the upper reaches of Jiyun River (Zhou river catchment) in North-East China, around $100 \mathrm{~km}$ in the North of Tianjin city center and around $100 \mathrm{~km}$ East of Beijing (400'30" - 40¹0'35" N, $117^{\circ} 30^{\prime} 42^{\prime \prime}-117^{\circ} 30^{\prime} 44^{\prime \prime}$ E) (Li et al., 2015). The reservoir has a surface area of $87 \mathrm{~km}^{2}$, a mean depth of $5 \mathrm{~m}$ and a maximum depth of $14 \mathrm{~m}$ at the dam. The elevation above sea level is $27 \mathrm{~m}$ at full capacity, and the total water volume is $1.510^{9} \mathrm{~m}^{3}$. The Luan River supplies the Yuqiao reservoir by converting water from the Daheiting reservoir with a rate of $10^{9} \mathrm{~m}^{3} /$ year. Besides the Luan River, major tributaries of the Yuqiao reservoir include the Li River, the Sha River and the Lin River, the latter two merging to Guo River before flowing into the Yuqiao reservoir. Outflow of Yuqiao reservoir is through the Zhou River (Figure 1) which supplies drinking water for Tianjin, a 6.5 million inhabitant metropolis. The catchment of the Yuqiao reservoir has an area of $2052 \mathrm{~km}^{2}$, covering parts of Hebei Province and Tianjin, with a local catchment population of 150000 inhabitants.

Once the unique source for Tianjin's industrial, agricultural and domestic use, Yuqiao reservoir played an important role in the development of the city. However, it has been undergoing serious eutrophication due to increased phosphorus inputs during the past two decades. Residents of the Yuqiao catchment live mainly off farming consisting of livestock husbandry (chicken, pigs, and fish) and grain and vegetables production. The total annual phosphorus loading from sewage and manure is estimated to be 73 and 365 tons, respectively (Orderud et al., 2015). Application of excessive amounts of inorganic phosphorus fertilisers and discarding of livestock manure are general practice in this region. The retain capacity for phosphorus of the soil is poor, mainly due to low organic content and a predominance of clay minerals with poor sorption capacity (Pettersen, 2014). The predominance of clay makes also the soil impermeable, and rainwater is stored in the shallow plough layer. During rainfall events, the shallow layer becomes quickly saturated and triggers flows over the surface or sub-laterally, flushing large quantities of phosphorus into the Yuqiao reservoir (Orderud et al., 2015; Pettersen, 2014).

\section{II.2. Data set}

A historical dataset collected between January 2008 and December 2012 in the center area of Yuqiao reservoir (HWCC unpublished data) was used for analyzing the 


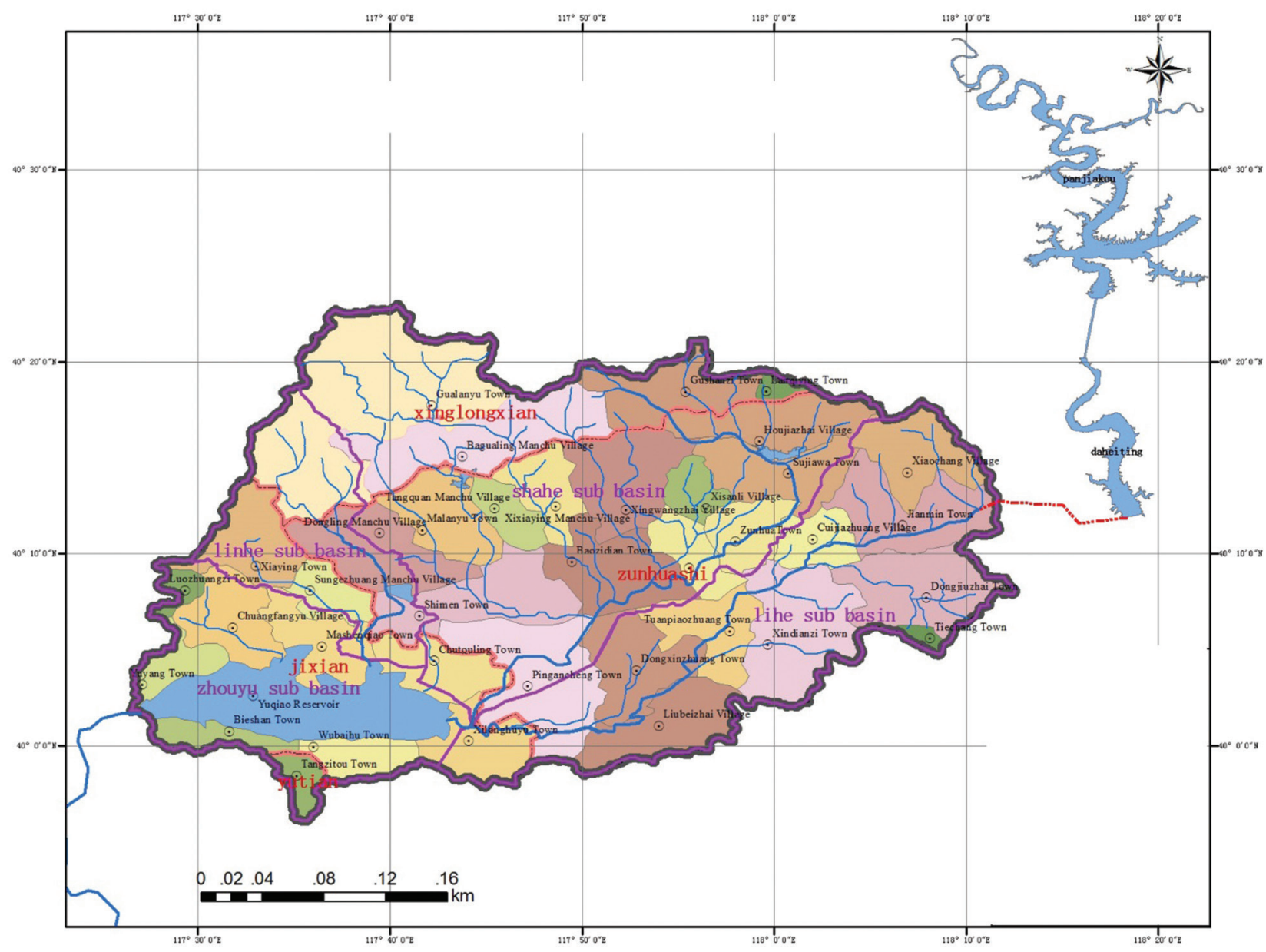

Figure 1: Map of Yuqiao reservoir and its catchment (from HWCC internal report).

interannual variability of the water temperature evolution and of the cyanobacteria dynamics. In 2014, a specific field campaign was conducted from July $22^{\text {nd }}$ to August $8^{\text {th }}$ at a sampling point located $1 \mathrm{~km}$ East of the dam $\left(40^{\circ} 2^{\prime} 1.68^{\prime \prime} \mathrm{N}\right.$, $117^{\circ} 27^{\prime} 22.32$ ”E). Water transparency was measured with a Secchi disk. Water temperature and chlorophyll-a profiles were measured daily, between 11:00 and 13:00 with a submersible multisensor probe (YSI $6600 \mathrm{~V} 2)$, The sensor measuring range is -5 to $+50{ }^{\circ} \mathrm{C}$ for water temperature with a resolution of $0.15^{\circ} \mathrm{C}$ and a range of 0 to $400 \mu \mathrm{g} . \mathrm{L}^{-1}$ for chlorophyll-a and a resolution of $0.1 \mu \mathrm{g} . \mathrm{L}^{-1}$. Hourly meteorological input data used for calibration were provided by a weather station located in Beijing area $\left(39^{\circ} 56^{\prime} \mathrm{N}-\right.$ $\left.116^{\circ} 17^{\prime} \mathrm{E}\right), 100 \mathrm{~km}$ West of the reservoir.

\section{II.3. Modelling approach}

We implemented a one-dimensional vertical model, based on the simulation of the main physical processes and coupled with a sub-model of the biological processes. The main physical processes which are driving the cyanobacteria growth are considered: the heat fluxes at the interface between air and water and the kinetic energy brought by the wind. The model computes the water temperature and takes into account the mixing and stratification processes. On the biological level, cyanobacteria growth is simulated; its primary production by photosynthesis is limited by temperature, light intensity and nutrient concentration. The GLM-FABM-AED modelling suite was used (Hipsey et al., 2014). GLM (General Lake Model) is a one-dimensional vertical model which simulates water balance, temperature and salinity. FABM (Framework for Aquatic Biogeochemical Models) is the computer interface which links the water quality model to physical model. AED (Aquatic EcoDynamics) simulates the dynamics of phytoplankton, zooplankton, nutrients, oxygen, carbon, and sediment. In Yuqiao model, we simulated only the cyanobacteria growth and nutrient dynamics. The variation of the reservoir water level was neglected for two reasons: firstly there was nearly no rainfall during our study period and secondly because at the time scale of short-term forecasting (5 days) the water level variation can be considered negligible. The output time step is one hour.

\section{RESULTS}

\section{III.1. Dynamics of cyanobacteria in Yuqiao reservoir}

Historical physical-chemical measurements performed between 2008 and 2012 (Figure 2) were analyzed. They allowed us to better understand the nutrient and phytoplankton seasonal evolution and its interannual variability. Between 2008 and 2012, subsurface water temperature in Yuqiao Reservoir ranged from 0 to $31.7^{\circ} \mathrm{C}$, chlorophyll-a from 1.3 to $52.2 \mu \mathrm{g} / \mathrm{L}$, transparency from 0.6 to $5 \mathrm{~m}$, total phosphorus (TP) from 0.01 to $0.12 \mathrm{mg} / \mathrm{L}$, orthophosphate from 0.004 to $0.04 \mathrm{mg} / \mathrm{L}$, total nitrogen $(\mathrm{TN})$ from 0.57 to 

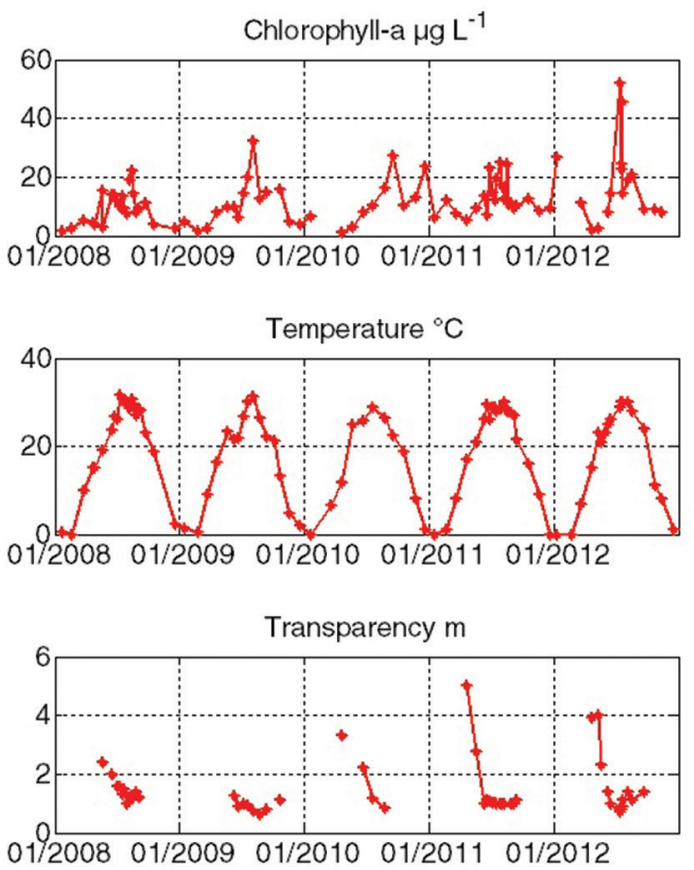
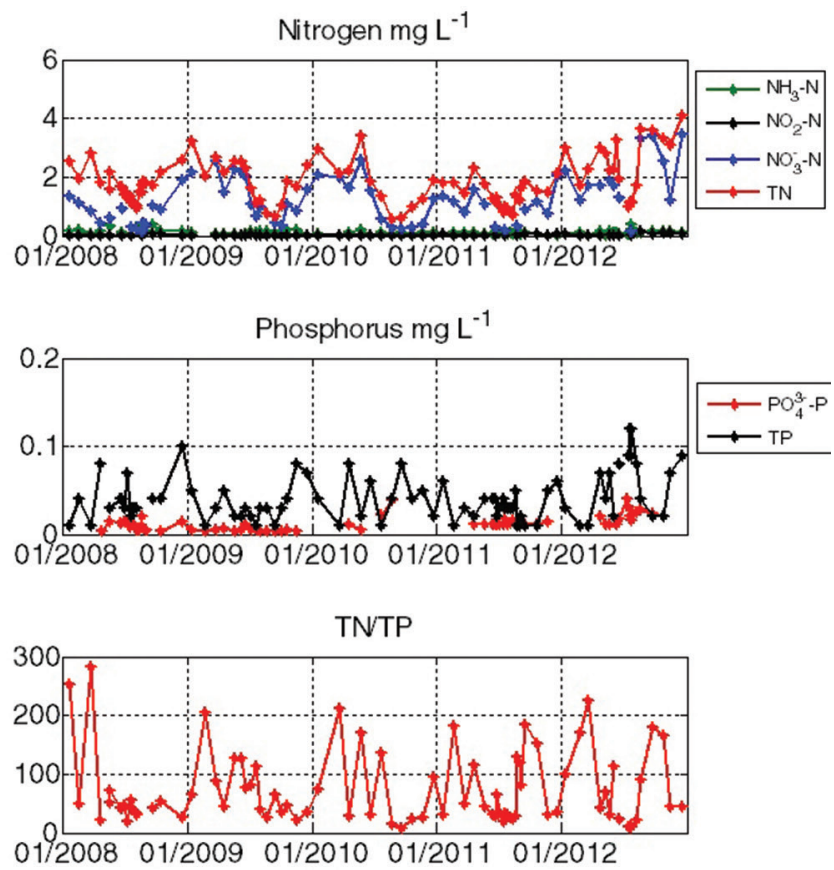

Figure 2 : Physical-chemical data taken at the center of Yuqiao reservoir between 2008 and 2012 (HWCC unpublished data).

$4.12 \mathrm{mg} / \mathrm{L}$, nitrite from 0.003 to $0.15 \mathrm{mg} / \mathrm{L}$, ammonia from 0.003 to $0.15 \mathrm{mg} / \mathrm{L}$ and nitrate from 0.15 to $3.45 \mathrm{mg} / \mathrm{L}$. The TN/TP mass ratio ranged from 8 to 283. The main cyanobacteria species in Yuqiao reservoir are Microcystis spp. The dynamics of the cyanobacteria biomass is highly correlated with water temperature. No clear relation can be established between the cyanobacteria and the nutrient concentrations that are available in high concentrations all year long due to high nutrient fluxes from the watershed of the reservoir. Through high values of the TN/TP ratio, we can conclude that phosphorus is the main limiting nutrient of phytoplankton growth.

\section{III.2. Model calibration}

We divided the 2014 data set into two periods: the first one from July $22^{\text {nd }}$ to July $28^{\text {th }}$ for calibration of the parameters and the second one from July $29^{\text {th }}$ to August $8^{\text {th }}$ for validation of the model.
The input data are the daily inflow and outflow values and the hourly meteorological data (sun radiation, cloud cover, air temperature, the relative humidity, wind speed and rainfall) measured in Beijing area $\left(39^{\circ} 56^{\prime} \mathrm{N}-116^{\circ} 17^{\prime} \mathrm{E}\right)$. The model outputs are the water temperature $\left({ }^{\circ} \mathrm{C}\right)$ and cyanobacteria biomass represented by chlorophyll-a concentration $(\mu \mathrm{g} / \mathrm{L})$.

The calibration of the model parameters was performed by minimizing the error between model results and measurements. GLM parameters were first calibrated. The calibrated parameters include the light extinction coefficient, the hypolimnetic Kelvin-Helmholtz mixing efficiency and the hypolimnetic turbulence mixing efficiency (Table 1). The maximum and minimum layer thicknesses are also triggered. Most calibrated parameters are close to default values. Wind speed data supplied by the weather station were decreased using a wind multiplication factor of about 0.6. The light extinction coefficient was consistent with values calculated from the Secchi depth measurements, between 0.6 and $5 \mathrm{~m}$.

Table 1 : Parameter values used for GLM configuration at Yuqiao Reservoir

\begin{tabular}{|c|l|c|c|c|}
\hline Symbol & \multicolumn{1}{|c|}{ Description } & Units & Default value & Used value \\
\hline$C_{K}$ & Mixing efficiency - convective overturn & - & 0.2 & 0.2 \\
\hline$C_{W}$ & Mixing efficiency - wind stirring & - & 0.23 & 0.23 \\
\hline$C_{S}$ & Mixing efficiency - shear production & - & 0.3 & 0.3 \\
\hline$C_{T}$ & Mixing efficiency - unsteady turbulence effects & - & 0.51 & 0.51 \\
\hline$K_{H}$ & Mixing efficiency - hypolimnetic Kelvin-Helmholtz turbulent & - & 0.3 & $\mathbf{0 . 1}$ \\
\hline$\alpha_{T K E}$ & Mixing efficiency - hypolimnetic turbulence & - & 0.5 & $\mathbf{1}$ \\
\hline$H_{\min }$ & Minimum layer thickness & $\mathrm{m}$ & 0.5 & $\mathbf{0 . 1}$ \\
\hline$H_{\max }$ & Maximum layer thickness & $\mathrm{m}$ & 2 & $\mathbf{0 . 4}$ \\
\hline$K_{W}$ & Light extinction coefficient & $\mathrm{m}^{-1}$ & 0.2 & $\mathbf{1 . 4}$ \\
\hline
\end{tabular}


The parameters involved in cyanobacteria growth were then calibrated (Table 2). The dynamics of only one cyanobacterium species, Microcystis spp., was simulated. This cyanobacterium was configured not to be subject to photoinhibition. A constant buoyancy velocity was used. Due to the absence of precise data about zooplankton biomass, the effect of zooplankton grazing on phytoplankton was not simulated; however, its contribution to phytoplankton mortality was considered in the model through a phytoplankton loss term that also included respiration and excretion.

The calibration results are presented for water temperature and cyanobacteria concentration as vertical profiles at the measurement dates (Figure 3). The cyanobacteria biomass is expressed as concentration of chlorophyll-a. A good agreement between model and data can be observed. Two performance indicators were considered, the root-mean square error (rmse) and the correlation coefficient $\left(\mathrm{r}^{2}\right)$ between measurements and simulation. For temperature, rmse is equal to $1.03^{\circ} \mathrm{C}, \mathrm{r}^{2}$ is equal to 0.91 . For cyanobacteria biomass, rmse is equal to $1.18 \mu \mathrm{g} / \mathrm{L}, \mathrm{r}^{2}$ is equal to 0.62 .

The validation results are also presented for water temperature and cyanobacteria concentration as vertical profiles at the measurement dates (Figure 4). An acceptable agreement within the range of the measured values is also obtained by the model. For temperature, rmse is equal to $1.69^{\circ} \mathrm{C}, \mathrm{r}^{2}$ is equal to 0.62 . For cyanobacteria biomass, rmse is equal to $1.66 \mu \mathrm{g} / \mathrm{L}, \mathrm{r}^{2}$ is equal to 0.48 .

\section{III.3. Forecasting}

The forecast model will anticipate cyanobacteria evolution over a 5-day period. It requires the meteorological forecast over the 5-day period and the water temperature and cyanobacteria vertical profiles measured on the first day of the simulation as initial conditions. With these input data the model computes the water temperature and the cyanobacteria biomass over the next 5 days.

In order to assess the possible range of the prediction, without conducting a deep uncertainty analysis, we considered two additional scenarios of weather forecast: a favourable scenario for cyanobacteria growth and an unfavourable one. The favourable scenario was based on the actual weather forecast but with $10 \%$ increase in the air temperature, $10 \%$ decrease of the wind speed and $10 \%$ decrease of the cloud cover. The unfavourable scenario was built in the same way but with $10 \%$ decrease in the air temperature, $10 \%$ increase in the wind speed and $10 \%$ increase in the cloud cover.

\section{III.4. User interface}

A user interface was developed with Python programming language for making easier the configuration of the simulation and for visualizing the results. The model can be applied in two different modes: forecast mode for short-term prevision and hindcast mode which allows the user to assess directly the model performance by comparing the field measurements and model outputs. The interface includes the possibility to save figures and to use different files for measured data and/or initial conditions.

The results of the hindcast modelling can be presented as contour plot of water temperature and cyanobacteria as function of time in the $\mathrm{x}$-axis and depth in the y-axis (Figure 5). The colour scale directly allows the user to visualize the temperature and chlorophyll-a gradients in the reservoir. Therefore, the use of the modelling interface makes it possible to use the model in the framework of the reservoir management.

The model outputs can also be compared to data on the days when the measurements were performed (Figure 4).

Table $2:$ Parameters used in FABM-AED to simulate cyanobacteria concentration in Yuqiao reservoir

\begin{tabular}{|c|c|c|c|}
\hline Symbol & Description & Units & Value \\
\hline$R_{\text {growth }}$ & Phytoplankton growth rate at $20^{\circ} \mathrm{C}$ & /day & 0.9 \\
\hline$Y c c$ & Carbon to chlorophyll-a ratio & $\mathrm{mg} \mathrm{C} / \mathrm{mg}$ chla & 40 \\
\hline$W_{P H Y}$ & Sedimentation rate & $\mathrm{m} /$ day & +0.01 \\
\hline$I K$ & Saturating light intensity & $\mathrm{microE} / \mathrm{m}^{2} / \mathrm{s}$ & 65 \\
\hline$K e_{P H Y}$ & Specific attenuation coefficient & $\mathrm{Mmol} \mathrm{C} / \mathrm{m}^{3} / \mathrm{m}$ & 0.001 \\
\hline$\theta_{\text {growth }}$ & Arrenhius temperature scaling for growth function & - & 1.08 \\
\hline Tstd & Standard temperature & ${ }^{\circ} \mathrm{C}$ & 20 \\
\hline Topt & Optimum temperature & ${ }^{\circ} \mathrm{C}$ & 28 \\
\hline $\operatorname{Tmax}$ & Maximum temperature & ${ }^{\circ} \mathrm{C}$ & 35 \\
\hline Rresp & Phytoplankton respiration rate at $20^{\circ} \mathrm{C}$ & /day & 0.02 \\
\hline Kfres & Fraction of metabolic loss that is true respiration & - & 0.4 \\
\hline Kfdom & Fraction of metabolic loss that is DOM & - & 0.05 \\
\hline$\theta_{r e s p}$ & Arrenhius temperature scaling for respiration & - & 1.08 \\
\hline$K P$ & Half-saturation concentration of phosphorus & $\mathrm{mmol} \mathrm{P} / \mathrm{m}^{3}$ & 0.001 \\
\hline$K N$ & Half-saturation concentration of nitrogen & $\mathrm{mmol} \mathrm{N} / \mathrm{m}^{3}$ & 4 \\
\hline
\end{tabular}



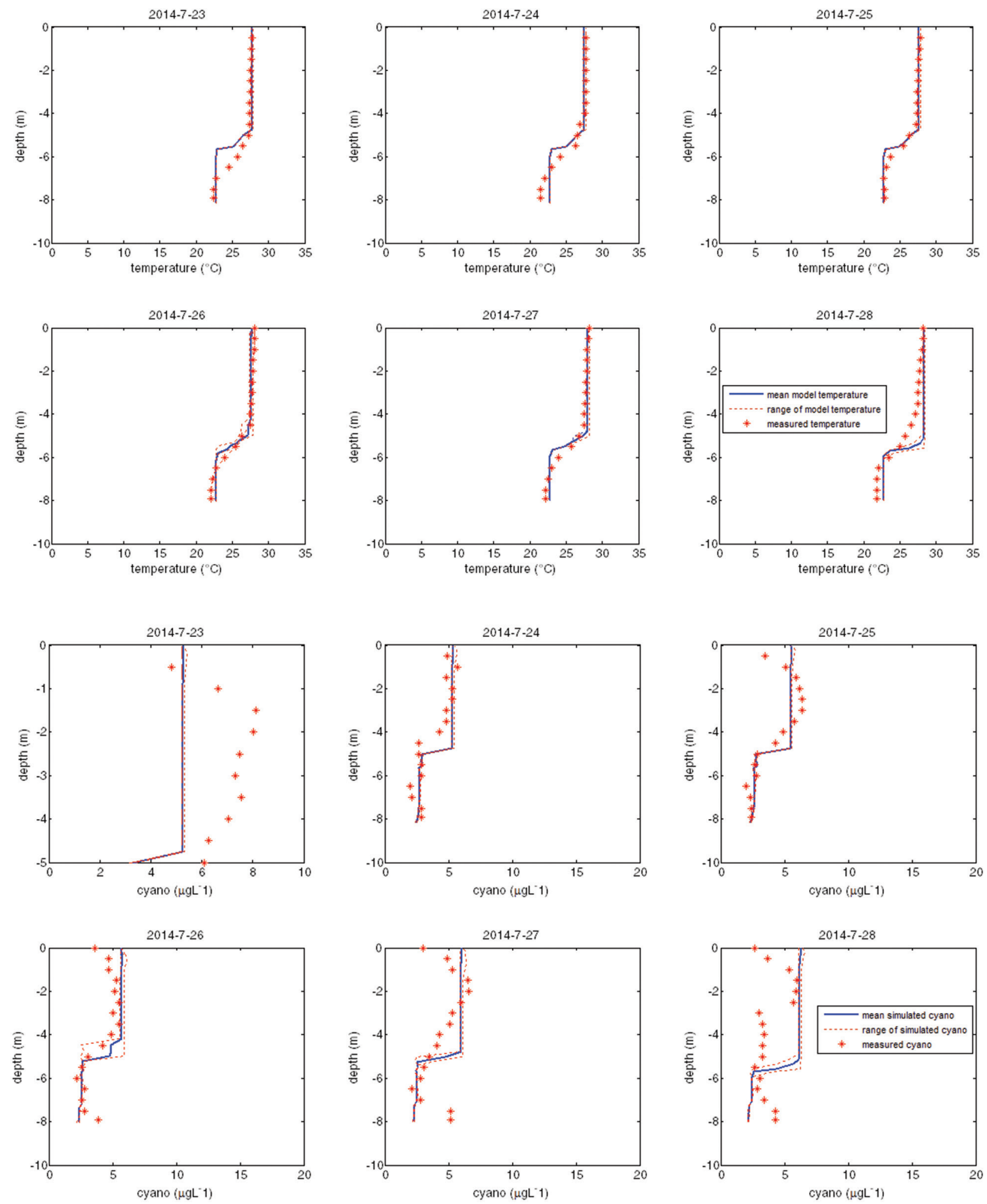

Figure 3 : Calibration period (22-28 July 2014): daily measured and simulated temperature (a) and cyanobacteria concentration (b) vertical profiles.

The last type of result comparison regards the average value over the whole water column or over a layer of specific interest.

In the case of forecast use of the model, three types of predicted results can be plotted (Figure 6): contour plots of water temperature and cyanobacteria forecast with the actual weather forecast, with favourable and unfavourable forecasts. The averaged values in a water layer of specific interest for the three scenarios can also be plotted. The World Health Organization (WHO) gives a chlorophyll-a concentration of $10 \mu \mathrm{g} / \mathrm{L}$ as the lower warning threshold in the guideline values for health protection (Chorus and Bartram, 1999). This threshold concentration is indicated in the figure as a red dotted line (Figure 7). 

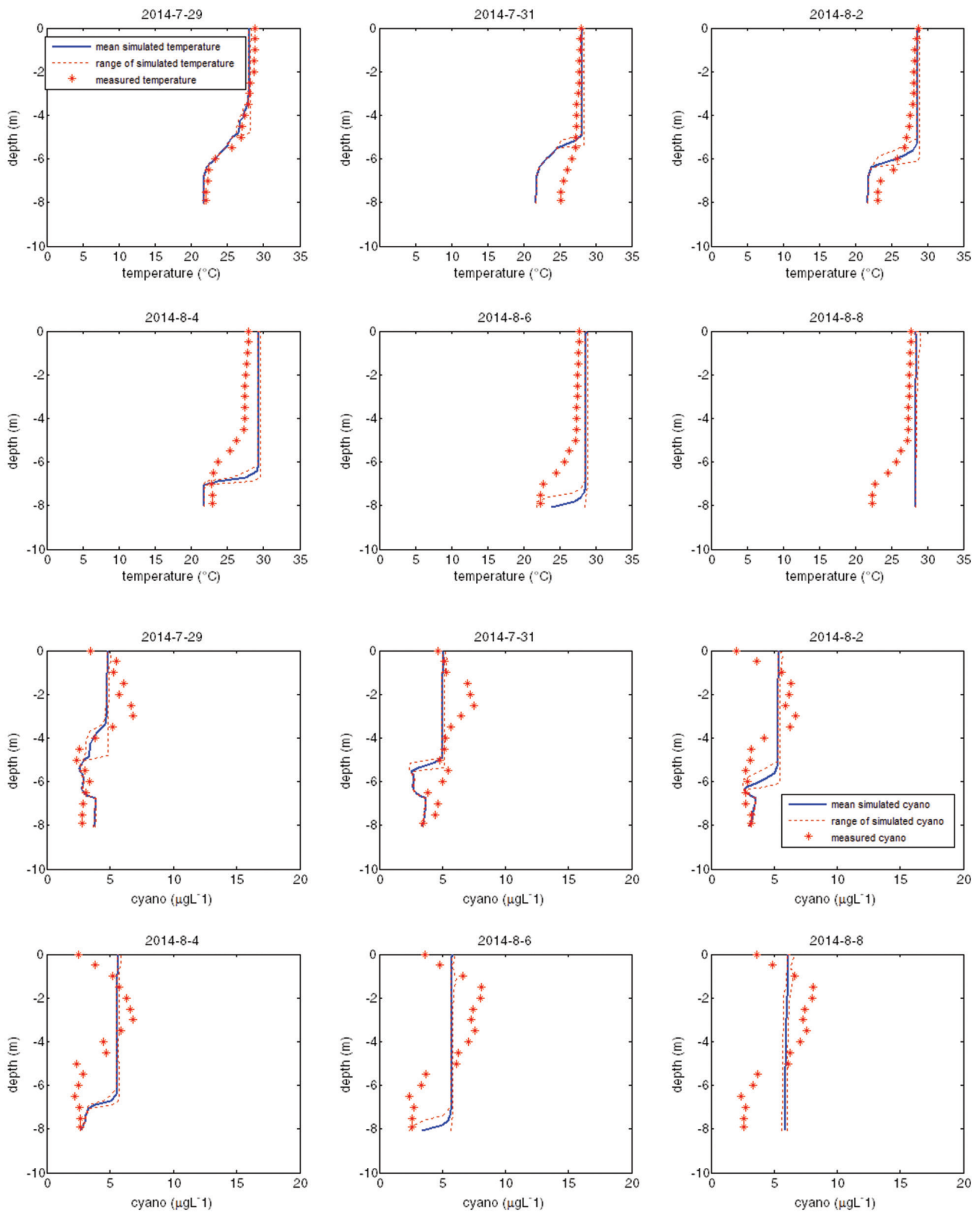

Figure 4 : Validation period (28 July - 8 August 2014): measured and simulated temperature (a) and cyanobacteria concentration (b) vertical profiles.

\section{DISCUSSION AND CONCLUSION}

This work is a first attempt to develop and adapt a simple forecasting model of cyanobacteria growth in Yuqiao reservoir. This one-dimensional vertical model is intended to anticipate cyanobacteria blooms using field data, water temperature and chlorophyll-a concentration, easily measured by off-the-shelf sensors at medium-frequency, daily or bi-weekly. The forecast horizon is 5 days. At this time scale, the main factors influencing cyanobacteria dynamics is the meteorological forcing. This fact exempts us to have very precise data concerning nutrient inputs. For longer term 

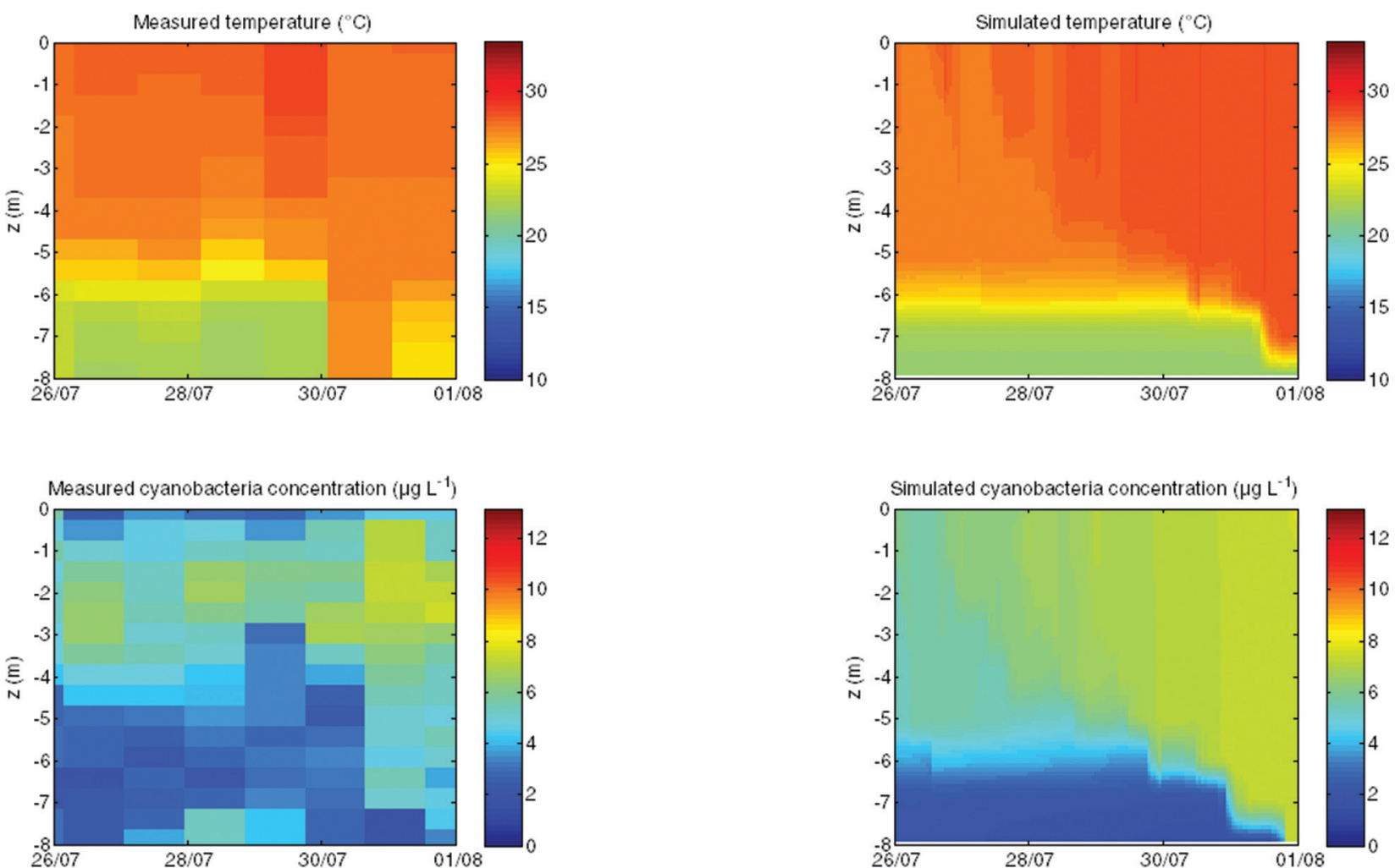

Figure 5 : Contour plots of measured and simulated temperature $\left({ }^{\circ} \mathrm{C}\right)$ and cyanobacteria concentration $(\mu g C h l / L)$ for a hindcast simulation (26-31 July 2014).
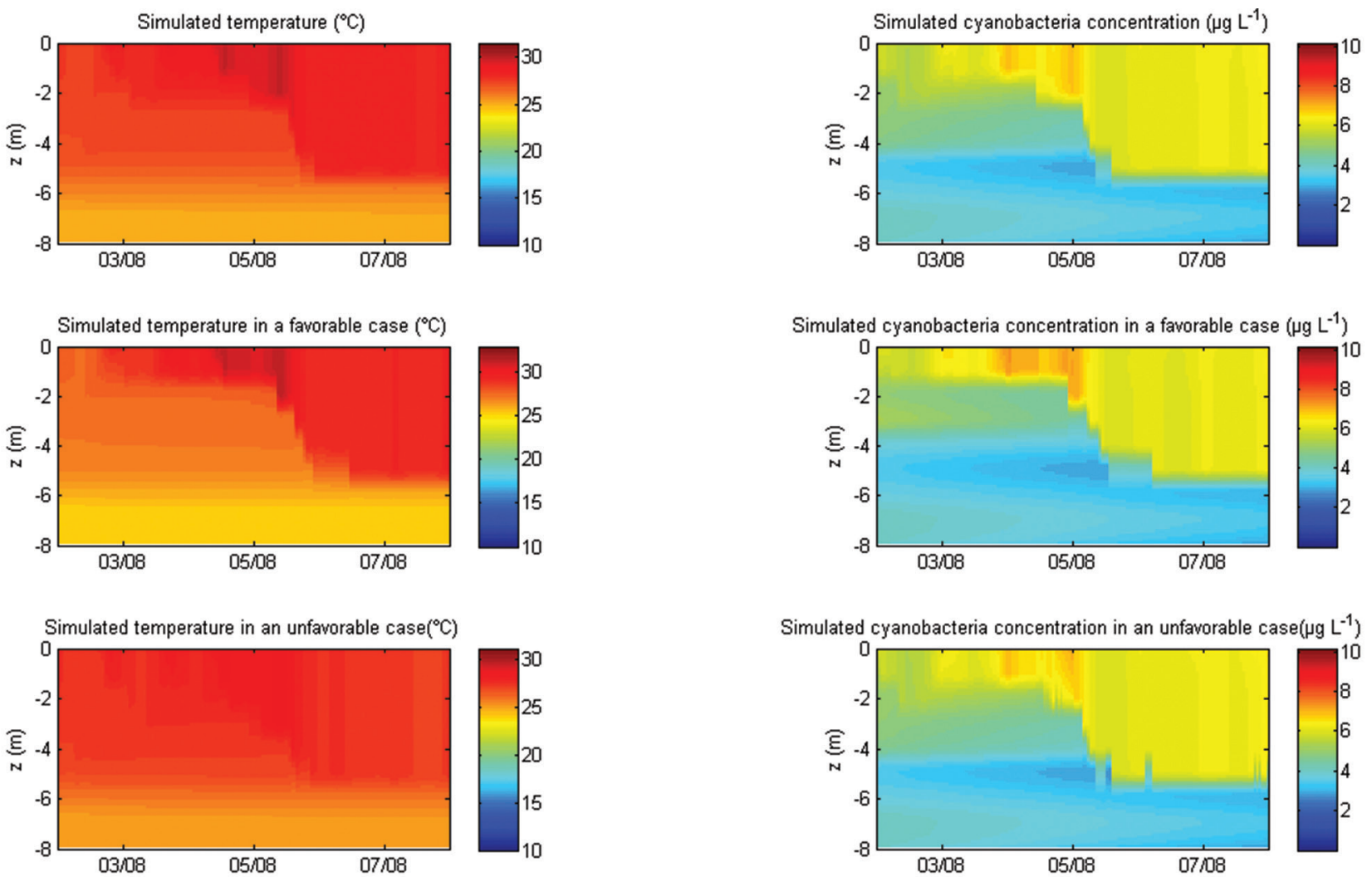

Figure 6 : Example of forecast simulation contour plots with the 3 meteorological forcing configurations. 

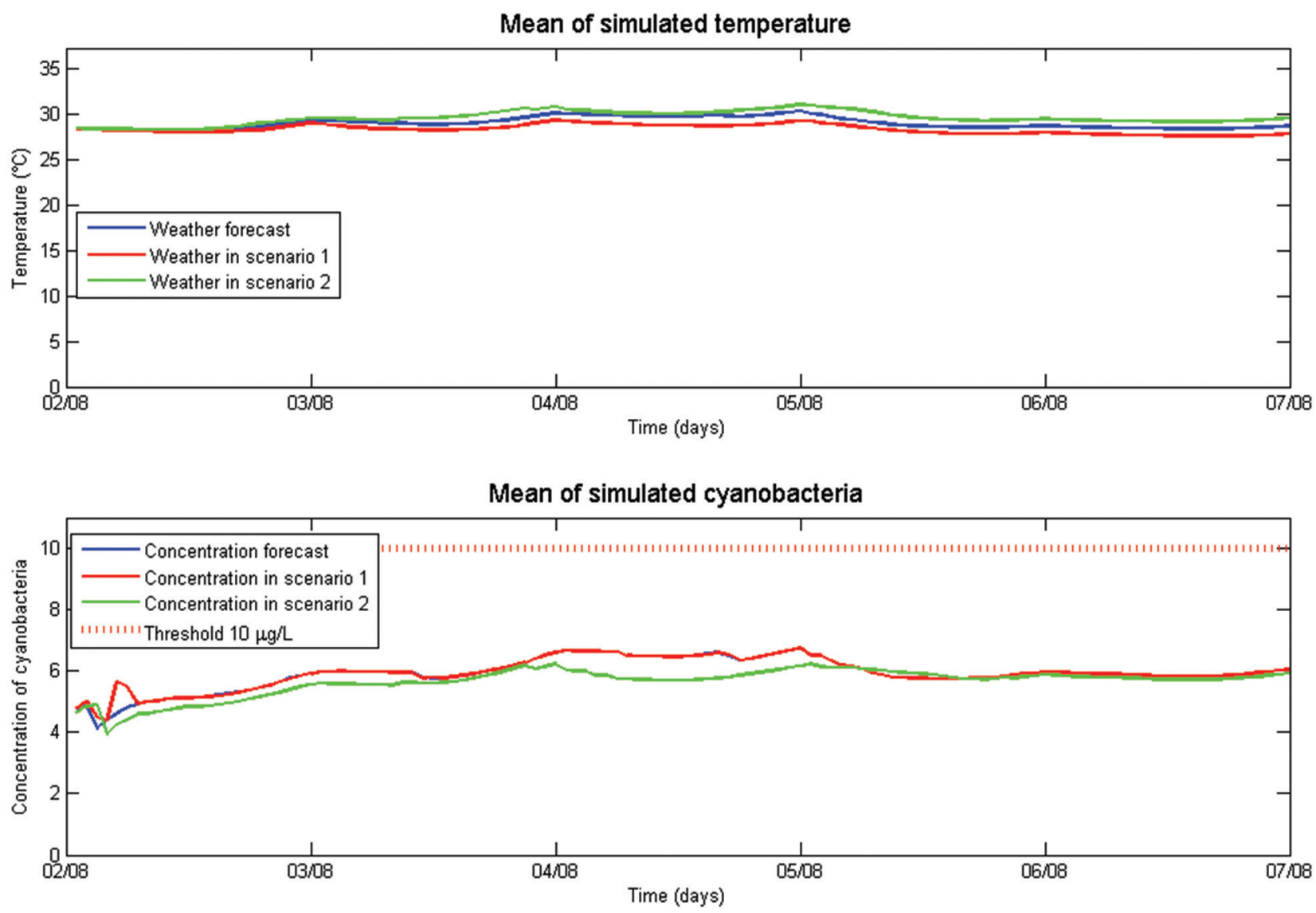

Figure 7 : Average temperature and cyanobacteria concentrations in the surface layer $(0-1.5 \mathrm{~m})$ corresponding to the forecast simulations of Fig. 6.

predictions, accurate knowledge of nutrient inputs would be required, but a predictive horizon of 5 days seems reasonably enough for management purposes.

The meteorological input data used for model calibration were provided by a weather station located $100 \mathrm{~km}$ west of the reservoir. Model outputs would be more robust in the future, if data from a closer meteorological station are used. The model parameters were calibrated with data collected over a 7-day period and validated over an 11-day period. An assessment of the model performance with a new data set is required. An uncertainty analysis will be conducted in order to improve the prediction range. After doing these additional steps, the model could be embedded in an on-line warning system.

\section{ACKNOWLEGMENTS}

This work was performed within the framework of a Cooperation project between the Ministry of Water Conservancy of China and the Ministry of Ecology, Sustainable Development and Energy (MEDDE) of France. The project partners are, in China, the Ministry of Water Resources, the Commission for Hai River Conservation and the Water Boards of Tianjin City and Hebei Province and in France, the Ministry of Ecology, Sustainable Development and Energy, the Seine-Normandy Water Agency, the Sanitation Authority of Greater Paris (SIAAP), the Institution of Great Lakes of the Seine (IBRBS). The project is coordinated by the International Office for Water (OIEau). The authors also warmly thank Dany Srage and Lucas Meyer, students at Ecole des Ponts ParisTech for their essential contribution in the user-interface development. The modelling study was supported by International Science \& Technology Cooperation Program of China (Grant No. 2013DFA71340) through an agreement with the Piren-Seine program.

\section{REFERENCES}

Anderson D.M., Cembella A.D., Hallegraeff G.M. (2012) Progress in Understanding Harmful Algal Blooms: Paradigm Shifts and New Technologies for Research, Monitoring, and Management. Annu. Rev. Mar. Sci 4 143-176

Chorus I., BARTRAM J. (1999) - Toxic Cyanobacteria in Water: a guide to their public health consequences, monitoring and management. World Health Organization, Geneva.

Curtarelli M.P., Alcântara E., Rennó C.D., Assireu A.T., Bonnet M.P., STech J.L. (2014) - Modelling the surface circulation and thermal structure of a tropical reservoir using three dimensional hydrodynamic lake model and remote sensing data. Water Environ. J. 28 516-525

Hipsey M., Bruce L.C., Hamilton D. (2014) - GLM - General Lake Model: Model overview and user information, AED Report \#26, The University of Western Australia, Perth, Australia.

Huo D., Luo Y., Nie Y., Sun J., Wang Y., Qiao Z. (2015) - The Distribution Characteristics of Microcystis novacekii Based 
on 16S rDNA Sequence, Zhang T.C., Nakajima M. (Eds.), Advances in Applied Biotechnology II 31-41

Jin K.R., Hamrick J.H., Tisdale T. (2000) - Application of three-dimensional hydrodynamic model for Lake Okeechobee. J. Hydraul. Eng.-Asce. 126 758-771

Li W., QIN B., ZHU G. (2014) — Forecasting short- term cyanobacterial blooms in Lake Taihu, China, using a coupled hydrodynamic - algal biomass model. Ecohydrology 7 794-802

Li X., Xu Y., Zhao G., Shi C., Wang Z.-L., Wang Y. (2015) Assessing threshold values for eutrophication management using Bayesian method in Yuqiao Reservoir, North China. Environ. Monit. Assess. 1874399

Mcquaid N., Zamyadi A., Prevost M., Bird D.F., Dorner S. (2011) - Use of in vivo phycocyanin fluorescence to monitor potential microcystin-producing cyanobacterial biovolume in a drinking water source. J. Environ. Monit. 13 455-463

Orderud G.I., Vogt R.D., Andersen T., Luo J. (2015) Explaining and understanding environmental actions in Chinese agriculture: the case of Yuqiao watershed of Tianjin municipality. Int. J. Sustain. Dev. World Ecol. International Journal of Sustainable Development \& World Ecology 22(6) 496-509

Pettersen E. (2014) - Soil phosphorus pools and their relation to land-use and soil physiochemical properties-A case study of an agricultural watershed in north-eastern China. Master Thesis, University of Oslo, Norway. Retrieved from https://www.duo. uio.no/handle/10852/42263

Recknagel F. (2013) - Current Scope, Case Studies and Future Directions of Ecological Informatics. J. Environ. Inform. 21 3-11

Ye L., CAI Q., ZHANG M., TAN L. (2014) - Real-time observation, early warning and forecasting phytoplankton blooms by integrating in situ automated online sondes and hybrid evolutionary algorithms. Ecological Informatics 22 44-51

Zhang H., Hu W., Gu K., Li Q., Zheng D., Zhai S. (2013) - An improved ecological model and software for short-term algal bloom forecasting. Environ. Model. Softw. 48 152-162 